
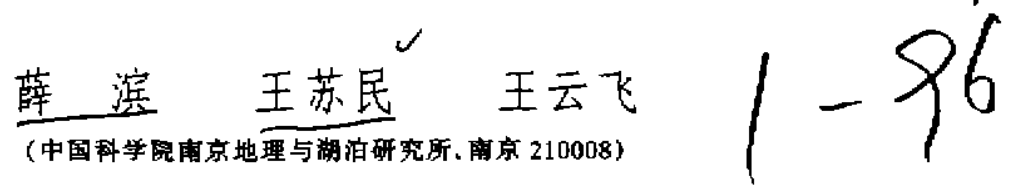

提 要 根据青芸高原东部若尔盖盆地 $\mathrm{RM}$ 孔、北部柴达木盆地 $\mathrm{ZK}-336$ 及 $\mathrm{CK}-6$ 孔和 㣀池盆地参 1 井等长孔的湖泊深钻记录。探讨了中更新世以来我国环境的区域分异特点、结合黄 土一古土算序列的研究成果，初步分析了导致区域环境分异的原因及其与亚洲季风的关系, 结果 表明青载高原在其中抬演很重要的角色.

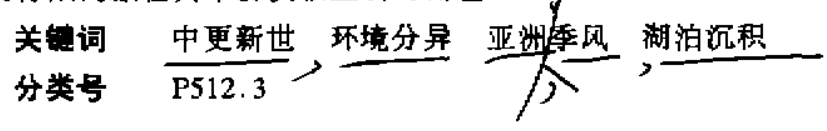

近年来, 湖泊沉积的研究愈来愈受到第四纪科学家的重视,并出台了“国际大陆钻探计划 (ICDP)"及相应的“古全球变化湖泊钻探计㚳”，其原因在于湖泊沉积物具有其它陆相记录，如 树轮、冰芯,甚至黄土不可替代的优势。长尺度的湖泊记录不仅能表现出气候的冰期/间冰期旋 回和构造运动的影响，同时又能反映短时间尺度气候的变率及其发生的边界条件 ${ }^{[1]}$. 然而, 我 国的湖泊沉积与过去全球变化研究刚刚起步，存在问题仍然很多,要研究东亚季风形成与发展 过程, 缺长时间尺度、连续和多环境指标的湖泊深钻记录。但是, 从仅有的几个长尺度湖泊记 录, 加上研究较为深入的黄土记录，还是能够为我们进行区域对比，探讨区域环境分异与亚洲 季风关系等提供一些信息.

我国已有的长时间尺度、详细研究的湖泊多集中在中晚更新世,如青藏高原东部的若尔盖 盆地、高原北部的柴达木盆地、云南的滇池盆地等等.若尔盖盆地 RM 孔是迄今青藏高原研究 最为深人的全取芯井,位于西风带南北两支的辐合区域, 同时也受西南季风的影响, 该井地面 海拔 $3400 \mathrm{~m}$, 深达 $310 \mathrm{~m}$ ，全并沉积岩性较细，由湖相粉砂质泥、泥质粉砂、粉砂构成，泥炭出现 的频率较高，底界年代达 $900 \mathrm{kaBP}^{[2]}$ ，柴达木盆地位于青藏高原的北部，海拔 $2880 \mathrm{~m}$ ，是高原上 最大的山间盆地, 受北西西和北东东两组断裂控制, 气侯上主要在西风带影响范围, 季风影唎 极为微弱,第四纪以来盆地处于长期沉降之中, 沉积了一套连续的湖泊地层, 已建立了 73 万年 来的气候演化序列 ${ }^{[3,4]}$. 滇池则处于西南季风(印度季风)的控制范围, 湖面高程 $1900 \mathrm{~m}$, 和青 藏高原处在不同的地貌单元上，参 1 井位于滇池北岸, 井深 $500 \mathrm{~m}$, 已达 300 万年, B/M 界限在 $139 \mathrm{~m}^{[s]}$ ，相对较粗的孢粉记录仍能提供中更新世以来的气候环境演化信息.

若尔盖盆地的分析研究较为深入，多学科的环境指标分析表明 $900-800 \mathrm{kaBP}$ 以暖湿和 冷干气候组合为特征; $800-480 \mathrm{kaBP}$ ，若尔盖古湖的生产力较高, 水深较大, 气温偏低, 以冷湿 环境为主导, 也是大规模冰川发育时期; 480-160kaBP，若尔盖古湖进入低生产力浅水时期,

- 国家科委及中国科学院吾大颔目萁助

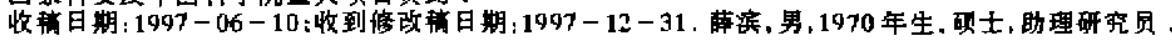


孢粉浓度与木本花粉含量极低, 冷水种介形虫占优势, 风成沉积发育, 趋冷趋干是本阶段的特 色: 160-0kaBP, 若尔盖古湖进入新的生产力高峰期, 木本植被发育, 降水较多, 蒸发量较小, 保持温凉湿润环境, 以暖湿和冷干的气候组合为特点,一直到湖盆被黄河切穿 ${ }^{[6.7]}$.

\section{1 湖泊深钻记录的比较研究}

目前可供较长时间尺度对比研究的湖泊沉积记录只有柴达木、滇池和若尔盖古湖, 这些单 井的长尺度气娭资料, 可以避免局部环境因素的干扰, 更多地辩析出大区域乃至全球气候变化 的特点, 进行长尺度的湖泊记录的对比, 结合研究较为深入的黄土记录, 就能更详细地了解我 国环境的区域分异, 以及和季风变迁的关系. 但是, 由于各个盆地采用的环境指标不一, 分析精 度相差甚大, 所以只能进行大的演化阶段的对比.初步的对比结果表明：

中更新世早期 $(780-480 \mathrm{kaBP})$ 青藏高原东部的若尔盖与北部的柴达木地区均以相对湿 润的环境为主导, 但云南高原似乎表现为暖干的气娭特点, 是否是海拔高度差别所致,仍然不 得而知, 黄土高原该时期黄土的堆积既粗又导, 磁化率为低谷, 代表典型的冷干环境 ${ }^{[8]}$.

中更新世晚期(480-160kaBP) : 柴达木盆地和若尔盖地区一样,均表现出明显的趋冷趋 干的气候特点, 柴达木盆地湖泊为一明显的退缩时期, 而云南高原, 与青藏高原相一致的是气 诶的变冷, 并且越到后期, 寒冷珵度更为加剧, 不一致的是该区明显番湿、看来 $480 \mathrm{kaBP}$ 开始 的气娭趋冷具有大区域范围的一致性, 深海的冰量也是一个极大时期 ${ }^{[9]}$; 而黄土高原黄土一古 土壤旋回的厚度加大, 气娭干湿变化更趋明显 ${ }^{[10]}$.

晚更新世(160-0kaBP) : 青藏高原柴达木盆地与若尔盖古湖两者湖泊记录的气候波动基 本一致, 但柴达木盆地基本表现为干旱的背景, 波动的幅度似乎也不及若尔盖盘地, 这可能在 于后者处于季风气候的边缘, 对气候变化的吽应尤为敏感. 尤其是若尔盖 RM 孔记录了末次 间冰期, 特别是其早期的气候剧烈波动 ${ }^{[11}$. 位于云南高原的滇池盆地, 和若尔盖地区也不一 样, 表现出变干的趋势, 并且与青藏高原地区在气候的组合上迥然不同, 冷期偏湿, 暖期偏干. 而黄土高原在这一时期表现得更趋干旱 ${ }^{[\mathrm{B}]}$.

\section{2 结果与讨论}

上述对比分析表明, 中更新世以来, 我国气俟环境存在明显的区域分异, 究其原因, 青藏高 原的隆升可能在其中扮演了一个非常重要的角色, 高原的隆升与东亚季风的发展密切相关.

青藏高原在中更新世前, 大面积的山地仍然没有进入冰冻圈, 我国中东部受季风气候的影 响, 大多为暖湿、冷干的气矤 ${ }^{[2]}$.

中更新世早期约 780 kaBP 高原开始全面进入冰冻圈, 3000-3500m 的海拔有利于水汽冷 凝, 促成冷湿气候条件下大规模冰川的发育, 同时北半球巨大冰盖的发育, 促使西风带南推, 由 于青藏高原高的海拔, 大气环流发生一次重大的改变, 使底层原他越高原的西风激流向高原两 侧绕流, 高空西风波槽增强、扰动加剧, 高原季风稳定建立, 它既可以激发强烈的西南季风，又 不至于明显阻挡水汽进入高原内部, 加上若尔盖处于西风带南北两支的辎合区域。冷湿的环境 尤为明显 ${ }^{[2]}$; 另外由于高原大范围的冰雪恶盖, 反照率增大, 形成稳定的高原冷高压, 使得西北 地区处在下沉气流环境, 塔里木盆地开始明显的沙漠化 ${ }^{[12]}$. 同时高原冷高医的加强, 使得西伯 利亚和蒙古高压也得到加强, 相应大大增强了冬季风携带粉尘的能力, 也抑制了东亚夏季风的 
活动，对应的黄土沉积既粗且厚，代表典型的冷干环境. 显然在北半球大气环流格局的形成中， 隆升的青藏高原起着重要的作用，所以中更新世早期的高原隆升，引起了明显的区域环境分 异, 高原本身是以冷湿为主导, 东部的若尔盖与北部的柴达木均为较湿的环境, 西北开始干旱 沙漠化, 黄土高原则为冷干环境.

$480 \mathrm{kaBP}$ 前后高原气候有一个明显的转型 ${ }^{[13,14]}$, 构造上升的累积效应使得高原明显趋 干 $^{[0]}$, 从大气环流的角度讲, 在于北半球大冰盖的萎缩, 西风带南支的北撤, 西风带主流线位于 高原以北, 原来气旋性质的西风带南支在松播地区形成的低压䏆消失, 高原东缘变得干旱, 高 原冰川同样萎缩, 高原的冷热源作用均较显著,东南季风区冬、夏季风均有加强, 季风气侯旋回 变幅加大,黄土一古土壤旋回更为醒目 ${ }^{[15]}$.西南季风区表现的不一致在于季风系统的不同.

$160 \mathrm{kaBP}$ 以来高原内部环境分异明显,西南季风区的滇池和西南季风边缘的若尔盖具有 不同的干湿趋向,而我国的黄土高原和西北地区却是干旱趋势明显.

中更新以来我国环境的区域分异似乎较为明显,其原因可能在于青藏高原的巨幅隆升及 相应的季风环流的变化,但其中具体的过程及构造 - 气候的佣合关系, 目前仍然并不清楚, 这 需要大量的陆相长尺度记录进行比较判别.

\section{参考文献}

1 Steven M Colman. Continental drilling for pelaeaclimatic records. PAGES Workshop Report, 1996, Series $96-4$

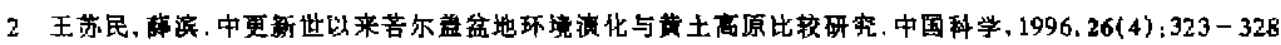

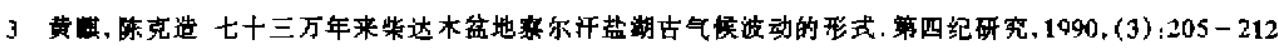

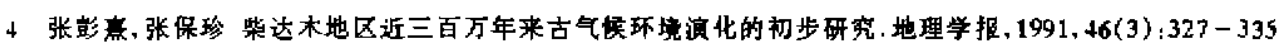

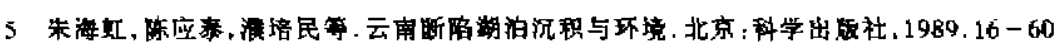

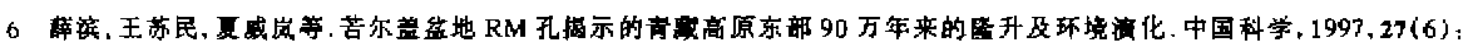
$543-547$

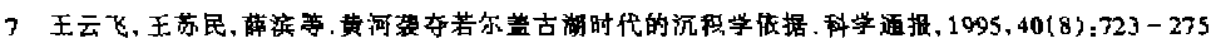

8 刘东生. 黄土与环境. 北京: 科学出版社, 1985

9 Shackleton N J, Opdyke N D. Oxygen isotnpe and palaeomagnetic, stratigraphy of Pacific core V28-239, L,ate Pliccene to latest Pleistacene. Geological Sactety of American Memuries, 1976, 145:449-464

10 Ding Z L. Yu Z, Rutter N W, et al. Towards an orbital time scale lor Chinese loess deposits. Quaternary Srience Revieu's, $1994,13: 39-44$

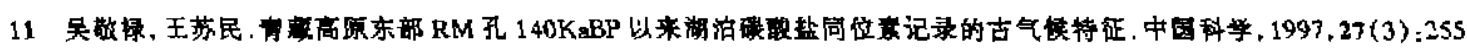
$-259$

12 Endo K, Yan S, Kanemakj M, et al. Evolution of Palaeoenvironments in Tarim Basin-Focussed on the development of Tak. limakan Desert. Journal of Geography, 1997, 106(2):145-155(in Japanese)

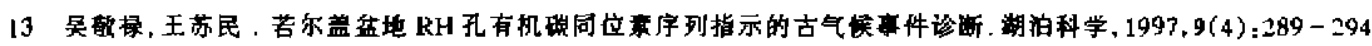

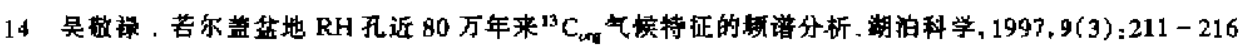

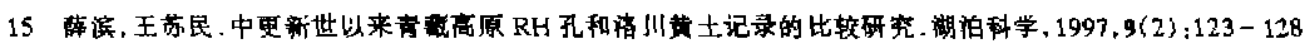




\title{
Regional Differentiation of Environment in China since Mid-Pleistocene Inferred from Lake Records and Its Relation with East Asia Monsoon
}

\author{
Xue Bin Wang Sumin Wang Yunfei \\ (Loke Sedimentution and Environtnent Ludmrasory, Nunjing Instusute of Geography and Lampuingy, \\ Chinese Arademy of Scuenıes. Nangung 210008)
}

\begin{abstract}
The lake records hawe proved their value by providing improtant insights into how global and regional climatic events influence continental ecosystems upon which humanity is most immediately dependent. Long records from single sites have the advantage of minimizing the effect of nonclimatic variables on the cycle-to-cycle palaeoclimate signal of climate proxies. The comparative study of the long core records located at different regions in China can provide some significant information about the regional differentiation of environmental evolution, and furthermore, about the Asia monsoon activities with the study on Loess plateau.

However, detalled lacustrine cores studied with a span of several $100000 \mathrm{a}$ are very rare in China. The available examples are only three long cores from the Zoige Basin in eastern Tibet (Qinghai-Xizang) plateau, Qaidam basin in northern Tibet plateau and Dianchi basin in Yunnan plateau respectively. The result has shown that there distinctively exist 3 stages since Mid-Pleistocene, i.e. $780-480 \mathrm{kaBP}, 480-160 \mathrm{kaBP}, 160-0 \mathrm{kaBP}$ for each of them the environment was of different and special characteristics in different regions of China. The result has also shown that the Tibet plateau has played a major role on the differentiation process. The comparison study is still in its infancy and more long cores are needed for us to probe into the uplifting of Tibet plateau and Asian monsoon evolution.
\end{abstract}

Key Words Mid-Pleistocene, regional differentiation, Asian monsoon, lake sediment 